\title{
Bantar Gebang: An Urban-Refuse Waste Picker Community at Indonesia's Largest Landfill
}

\author{
Michael P. Oman-Reagan \\ Department of Anthropology \\ Memorial University of Newfoundland
}

\begin{abstract}
:
This paper discusses Bantar Gebang, a landfill site twenty miles east of Southeast Asia's largest city Jakarta, Indonesia and considers the landfill as an extension of Jakarta's urban residential space. The discussion includes geography and political economy of the landfill and of Indonesia, as well as the lives of Indonesian Waste Pickers, and other related communities. Documentary films about Global waste picker communities as well as political organization among these communities are analyzed.

Keywords:

Waste, Indonesia, Landfills, Trash, Refuse

\section{Please cite as:}

Oman-Reagan, Michael P. 2012. "Bantar Gebang: An Urban-Refuse Waste Picker Community at Indonesia's Largest Landfill.” SocArXiv, Open Science Framework. Manuscript, submitted January 23, 2017. osf.io/preprints/socarxiv/pq7p2
\end{abstract}

At Bantar Gebang, a landfill site twenty miles east of Southeast Asia's largest city Jakarta, Indonesia $^{1}$ over 2,000 families live and work on an 80-foot-high mountain of refuse (Hodal 2011). Seventy-five percent of Jakarta's trash is delivered in daily truckloads which add over 900,000 cubic feet (Pasang et al 2007:1927) ${ }^{2}$ and around 6,600 tons per day to the landfill (Hodal 2011). Residents live in danger of health problems ranging from infections to tapeworm and malnutrition, and under threat of landslides on the mountain of trash (Hodal 2011). The waste picker $^{3}$ community also has weekly film screenings at an outdoor cinema built from scavenged parts, and they worship at an on site mosque led by a resident Imam (Hodal 2011). Residents tell

1 Population of the greater metropolitan area is around 21 million.

2 Pasang cites this percentage from: Cleansing Department, 2005. Draft Final Report Solid Waste Management for Jakarta: Master Plan Review and Program Development. Cleansing Department of Jakarta, PT Unisystem Utama, IRMA ASIA Pty Ltd, Jakarta.

3 In 2008, the term waste picker was chosen as the English language term of preference by attendees at the First World Congress of Waste Pickers. 
stories of meeting their partners at the landfill (Hodal 2011). Waste pickers are working, living and loving in this community, and yet it is also the destination for all things deemed "trash" by the Jakarta metropolitan region.

Although the landfill is outside of urbanized land, ${ }^{4}$ and despite the twenty miles separating Jakarta's city boundary and Bantar Gebang, I suggest here that it is an extension of Jakarta's urban space. In order to explore that relationship in this paper I look at Bantar Gebang from several perspectives: as a product of uneven development and modernization in Indonesia, as an archipelagic community of urban residents outside the periphery of Indonesia's mega-city, as a part of the "ruins of empire" (Stoler 2008), as a challenge to "regimes of disposal" (Endensor 2005), and as part of emerging transnational social movements for the rights of waste pickers, peasants and indigenous people. To do so, I look at reports in popular media, academic articles, waste management and urban planning literature, popular culture, films, and Indonesian Facebook pages and groups.

4 Based on NASA Landsat maps of urbanization in the region. 


\section{The Jakarta Billionaires Club: Development, Wealth \& Urbanization in a Global Mega- City}

"Indonesia exhibits the highest growth rate among [high net worth individuals] in all the countries we have looked at."

-- Stefan Hofer, Executive Director, Julius Baer, September 2012

An article published in the Jakarta Post on September 28, 2012 titled "Billionaires club grows fastest in Indonesia" (Grazella 2012) opens by declaring "the billionaires club in Indonesia is set to welcome new members" and describes how in its latest "Wealth Report," Swiss banking group Julius Baer has identified Indonesia as a frontrunner of "wealth creation" in Asia. The banking group measured "wealth creation" by looking at the number of "high net worth individuals" (HNWI), defined as those with "investable assets surpassing one million U.S. dollars, excluding their primary residences" (Grazella 2012). By 2015, the report predicts, these high net worth Indonesians could collectively hold assets of 518 billion U.S. dollars. This increase in "HNWI" in Indonesia reflects the country's position as a newly emerging, recently industrialized country which has quickly become the largest economy in Southeast Asia.

In November 2010, U.S. President Barack Obama returned to his childhood home in Indonesia and spoke to an audience of several-thousand young people at the University of Indonesia in Jakarta. He peppered his remarks with Bahasa Indonesia, the lingua franca of the archipelago, and shared memories of his life there in the 1960s. He spoke of flying kites, chasing dragonflies and the mango tree in front of their home. His colorful speech described the transformation of Indonesia in the intervening 40 years as a progression from "fields with water buffalo and goats" to "cell phones and social networks" (Obama 2010). This development discourse reflects the inequality-producing modernization occurring in Indonesia today with encouragement of economic powers like the United States. In his book, The Audacity of Hope, ${ }^{5}$

5 Obama, Barack. 2006. The audacity of hope: thoughts on reclaiming the American dream. Random House 
Obama writes that "for the past 60 years the fate of [Indonesia] has been directly tied to US foreign policy," including "the tolerance and occasional encouragement of tyranny, corruption, and environmental degradation when it served our interests." The growing dominance of neoliberal economic policy in the United States has been reflected in Indonesia's modernization, and reflects the product of multiple histories of occupation, colonialism and empire in the archipelago.

The boundary that defines present day Indonesia does not correspond to a traditional culture, state or polity, it was and continues to be inherited from the colonial encounter (Boellstorff 2005:7). The Indonesian national philosophy of Pancasila, created by Sukarno and set forth in the 1945 constitution, ties all Indonesians together under a national identity not despite of but in light of their diversity. Anthropologist Tom Boellstorff notes that anthropologists in Indonesia have historically looked at the region in terms of islands of distinct ethnolocalities, taking the people, culture and language of Bali or Java as subjects, for example rather than Indonesians more broadly (2005). To counter this ethnolocal tendency in his ethnography of gay and lesbi Indonesians ${ }^{6}$ whom Boellstorff argues engage with their identities at a national level, he uses a metaphor of "archipelagic subjectivities" which "do not hew to continental imaginaries of clear borders embracing contiguous territories" and reflect the national philosophy of diversity in unity, an "archipelago concept" (2005:7).

Drawing on this archipelagic frame, Bantar Gebang can be seen as both an island outside of the urbanized Jakartan metropolitan area and also a local area in Jakarta's urban community. In Planet of Slums, Mike Davis cites David Drakakis-Smith discussion of "extended

Digital, Inc.

6 The Indonesian terms/identities gay and lesbi do not map well onto the English terms gay and lesbian, and Boellstorff's work is not about a GLBTQ community as it is understood to exist in contemporary North America. 
metropolitan regions" which he argues:

"represent a fusion of urban and regional development in which the distinction between what is urban and rural has become blurred as cities expand along corridors of communication, bypassing or surrounding small towns and villages which subsequently experience in situ changes in function and occupation" (Davis 2006:10).

In Indonesia, Davis notes "a similar process of rural/urban hybridization is far advanced in Jabotabek (the greater Jakarta region) [. . .] researchers call these novel landuse patterns desakotas ("city villages") and argue whether they are transitional landscapes or a dramatic new species of urbanism" (Davis 2006:10). Davis argues that the rise of a global middle class in Asia comes at the expense of transferring wealth away from the poor who are increasingly pushed to the periphery of Asia's mega-cities, and into informal economies (Davis 2006) like that at Bantar Gebang. As a result, "sprawling outer zones" of cities are housing not only rural populations migrating toward cities, but those being forced out of cities by evictions and rising rents (Davis 2006). As the billionaires club grows in Indonesia, so do these peripheral rural/urban zones.

Following the economic modernization policies of Suharto's "New Order" in the mid to late 1960s (in contrast to the previous anti-western "Old Order" policies of Sukarno) Jakarta grew extremely fast. In the 20th century the population of Jakarta increased from about 100,000 in 1900 to more than 9 million in 1995 and most of that population was added between 1975 and 1995 (Han \& Basuki 2001). During this period of rapid development middle and high income families moved away from the central city to suburban gated communities while at the same time poorer Jakartans were forced to the periphery between the suburbs and the urban core due to the expansion of development in Jakarta's center and the consequent rent increases and lack of housing (Firman 1998, Leaf 1994, Cybriwsky \& Ford 2001).

As migration to Jakarta continues to grow and as poor Jakartans are pushed to the 
periphery, new squatter settlements, known as kampungs (villages) have emerged in the periphery of Jakarta (Cybriwsky \& Ford 2001). The kampung (village in Indonesian) is associated with informality, poverty, and the maintenance of rural traditions in an urban setting. Their emergence in Jakarta has been read as a sign of spatial segregation and socio-economic disparity in Indonesian urban life (Firman 2004).

Bantar Gebang was established near the Jakartan commuter city Bekasi as a landfill in 1989 in an area that was primarily forest (Tipple 2009). Attempts have been made to redirect some of Jakarta's trash to other areas, but protests from residents near the proposed sites have prevented establishing additional landfills in the area (Tipple 2009). An NGO working with children at Bantar Gebang estimates as many as 550 children ages 7 to 15 work at the dump to help their parents with $74 \%$ of the working children under age $12 .^{7}$ The creation of Bantar Gebang in the late 1980s marks it as a product of the dictator Suharto's rule (1980-98). His "New Order" regime was prefaced with the 1965-66 massacre of members or suspected members of the Partai Komunis Indonesia (Indonesian Communist Party, or PKI) an anti-communist purge that paved the way for his thirty-year rule. Some of Suharto's earliest economic policies focused on reversals of the pro-communist policies of Sukarno through privatization of Indonesia's state owned companies. This included selling resource extraction rights to American and European corporations (although this also occurred under Sukarno). As Indonesia entered a period of industrialization new class divisions resulted in increased poverty, hunger, and dislocation of rural people.

\section{Pemulung and Indonesian Waste Pickers}

The most common Indonesian word I found used to describe waste pickers was pemulung

7 U.S. Department of State, Country Reports on Human Rights Practices - 2000, February 2001

M. Oman-Reagan 6 
(scavenger), sometimes combined with pengemis (beggar) as pemulung pengemis (scavenger beggar). This language reflects the highly marginalized position that waste pickers are placed in by Indonesian popular culture. Ethnographic information about the waste pickers at Bantar Gebang is scarce. Beyond journalist's reports of interviews with waste pickers, only a small number of Indonesian academics (all graduate students) have conducted work at the site and only one thesis contains ethnographic material. The dissertations are not available in English and to date there appear to be no publications in English on the landfill site. In one Indonesian dissertation focusing on the effects of changing labor structure on the informal economy, the researcher concluded the waste picker community is divided between "native scavengers" and "newcomers" and "settled scavengers" and "unsettled scavengers" (Simanjuntak 2002). Based on the language used in the dissertation, it was unclear whether this was a self-identified division, or one constructed by the author, however the distinction echoes what I found during my online fieldwork.

In 2010 Indonesia emerged as Facebook's second largest market (Cutler 2012). While many Indonesians do not have access to computers at home, the use of mobile devices to access the internet provides access to social media sites like Facebook and Twitter with little degradation of user experience. Because of the limited resources in the academic literature on Bantar Gebang, I chose to further investigate the waste picker community by conducting fieldwork on Facebook. During my fieldwork (from September to December 2012) I searched for and read through Facebook groups and pages using the key words "waste picker," "Bantar Gebang," and "pemulung." My familiarity with both the Indonesian language and online practices from my previous year of fieldwork among Indonesian activists on Facebook assisted in the research. 
My searches for pemulung and Bantar Gebang on Facebook brought me to a few different sorts of pages. Some were personal pages sarcastically claiming the identity of a pemulung. The others were pages associated with groups at the landfill site or on behalf of the site, such as "PeduLi Pendidikan Anak Pemulung Bantar Gebang, SKS (SekoLah Kampoeng Sampah)"8 (Care Education Scavenger Bantar Gebang, SKS (School Kampoeng Garbage)) an advocacy group for the education of waste picker children. The group description framed waste picker lives as struggles for survival and described the impact of that struggle on their children's educational prospects:

\begin{abstract}
"Kondisi Masyarakat yang hidup di daerah Bantar Gebang sebagian besar adalah masyarakat yang kehidupannya serba kekurangan. Sebagian dari mereka mata pencahariannya adalah pemulung. Hidup mereka hanya digantungkan pada sampahsampah yang berserakan disekitar rumah mereka, dimana terdapat tempat Pembuangan Akhir Sampah hasil buangan dari Pemerintah Provinsi DKI Jakarta. Keuntungan dari menjadi pemulung tidak begitu menghasilkan banyak keuntungan, sehingga banyak dari mereka yang tidak mampu membiayai anak-anak mereka untuk bersekolah. Hal ini mengakibatkan anak-anak mereka menjadi kurang pengetahuan dan ketinggalan dibanding anak-anak sebayanya. [. . .] kami merasa mempunyai Tanggung jawab atas apa yg terjadi dengan kondisi masyarakat di bantar gebang, Khususnya Anak2..."
\end{abstract}

(The condition of the community living in Bantar Gebang is mostly underprivileged. Some of them make their livelihood as scavengers. Their lives are hanging on the garbage strewn around their homes, where there is a garbage landfill produced by the waste from the provincial Government of DKI Jakarta. Being a scavenger does not produce much profit, so many of them can not afford to pay for their children to attend school. This has resulted in their children becoming less knowledgeable and missing out compared to other kids their age. [ . . . ] we feel responsibility for what is happening with the condition of society in bantar gebang, particularly [with the] Children .... $)^{9}$

8 https://www.facebook.com/pages/PeduLi-Pendidikan-Anak-Pemulung-Bantar-Gebang-SKSSekoLahKampoeng-Sampah/145589041322

9 Translation is my own. 
A Facebook user visiting this page posted a link on the timeline of the page to another Facebook page for a short film called "GUK!" which is the story of a young boy waste picker set at Bantar Gebang. The post, written in mixed Indonesian and English reads "coming soon! film tentang anak Bantar Gebang, like us!" (coming soon! a film about the children of Bantar Gebang, like us!" I followed the link to investigate.

On the Facebook page for the short film, ${ }^{10}$ several film posters posted to the timeline depict a young boy and a dog framed by mountains of trash. The description for the page and the film reads "a boy, a dog, and survival of the fittest." The posted "Plot Outline" provides a more narrative version of the plot: "once upon a time, a scavenger boy finds flyer of a missing dog, that will change his life." These two different descriptions of the film reflect end points on a continuum of waste picker identity that I encountered across Indonesian academic literature, advocacy and popular media. This "pemulung continuum" spans depictions of the waste picker as hard working settled survivor, adapting to changing conditions and a new economic reality across the continuum to portraits of the waste picker as a romanticized, transient, adventurer. Across this continuum, the waste picker is framed as both a necessary, logical response to the problem of waste, but also as a person living outside the bounds of normal, respectable, responsible society. Despite the economic transformations that have produced the urban refuse zone and the economic imperatives leading people to live there, the existence of the waste picker community is frequently framed only as a result of the failure of well planned solid waste management. These contradictions and tensions between pity, respect and necessity in the pemulung continuum are summed up well in a June 2012 opinion piece from the Jakarta Globe:

Scouring garbage dumps across the capital, they work in filthy conditions. No wonder people often look down on them. At many establishments, there are "Pemulung Dilarang Masuk" (No

10 https://www.facebook.com/pages/GUK-short-film/175883655771404 
Scavengers) signs posted.

At the same time, every household, business or shopping mall produces waste and needs to get rid of it daily. [. . .] When I look at them I realize how lucky I am and I'm grateful. I hope in the notso-distant future that Indonesia can implement an effective solid waste management program to stop people from scavenging and ideally, puts them to work in the formal sector. Until then, let us learn to humanize scavengers and respect the function they serve, because who knows; your branded purses could be made from trash picked up by them. (Bainbridge 2012)

\section{Imperial Trashscapes: Documentary Film, Ruins of Empire and Regimes of Disposal}

Global waste picker communities have been the subject of documentary films, such as Manufactured Landscapes (Baichwal 2006), Jennifer Baichwal's documentary about Edward Burynsky's photographs of environmental and social waste-lands. The subject of Burynsky's images are landscapes resulting from industrialization but in the film the photographer also visits e-waste workers (electronic waste pickers) in China. In Manufactured Landscapes (Baichwal 2006), one scene depicts a Chinese waste picker finding the remains of an iron and setting it aside as a valuable salvage, the film then cuts to the Sentai Electrical manufacturing plant where a young Chinese woman is assembling a new version of a similar iron in a factory. The blurb for the film describes these "industrial vistas" as "great shots" and "strange beauty" (Baichwal 2006). The film shows workers engaged in the construction of the industrial products and also those who deal with the remains of those industrial processes tracing the path from manufacture to destruction and reclamation.

Another film, Waste Land (Walker, et al. 2010), chronicles artist Vik Muniz as he visits a waste picker community outside of Rio de Janeiro at Jardim Gramacho, where he engages the workers to construct large scale portraits using the waste. Muniz then photographs the waste 
portraits and exhibits the photographs in art galleries. At Jardim Gramacho pickers sort out recyclables and sell them on site. The documentary begins with his appearance on a late-night television show, where the host introduces him by saying he "gives life to garbage" (Walker, et al. 2010). Garbage in this case is presumed to be dead, infertile, lifeless - in need of the inspired artist, and the market dealing in his work to infuse it with value. Both of these popular media representations depict waste picker communities through the gaze of the European/North American contemporary artist.

In one scene in Waste Land (Walker, et al. 2010) Muniz sits in his luxuriously appointed Brooklyn home, looking at his computer with his wife, and says:

This is probably the roughest...people you can think of, y'know they're all drug addicts, they're, they're, they're, um...it's like the end of the line.... Check out the geography of this thing [pointing to the location of the landfill on Google Earth] it's like the end of the line. This is where everything that's not good goes...including the people.

Later, after working with the waste pickers, he is interviewed in the kitchen of his Brooklyn apartment, surrounded by bowls of fresh food and shining appliances:

It could be me, I mean from the stories these people tell, a lot of them, they were, low... middle-class people, that for some unfortunate... uh, event they just ended up having to go there and live in the garbage.

Earlier in the film, during a debate with friends about the ethics of working with the waste pickers, his tendency to see the waste pickers lives as the result of their personal decisions first emerges when he suggests that after he takes the pickers to London they might choose to do something else, or choose to change their lives. Jardim Gramacho landfill is now closed and has been transformed into a methane recapturing plant. The waste has gained value yet again, but for the capitalists instead of the waste pickers through the mechanisms and market logics of resource 
extraction.

Manufactured Landscapes (Baichwal 2006), acknowledges the path from manufacture to destruction and reclamation, but ignores the power involved and the underlying reasons that the iron is being manufactured in China and recycled in China. Waste Land (Walker, et al. 2010) is beautiful portrait of individual emotional experiences on the one hand, but an ahistorical, twodimensional portrait of waste pickers from a structural perspective. The waste pickers in the film are given a moment of fame at an art gallery by an artist who arrives to lift them from poverty, after which they are returned right back where they started. Alternatively, I propose considering the waste picker communities in terms of their position in relation to two ways of thinking about power: histories and remains of colonialism and imperialism, and maintenance of order through control over trash.

Anthropologist Ann Stoler (2008) notes that colonial processes are predicated on claims of protecting natural and cultural inheritances for an indigenous population assumed to be in need of guidance in order to value and appreciate their inheritance. Investigating "protracted imperial processes" Stoler looks at "imperial formations" as relations of contemporary force evident in the "ruins of empire" and asks: how does colonial history matter? what do people count as remains? and what do they do with these remains? (2008:192-6). By asking how people "live with and in ruins" Stoler seeks to redirect the engagement away from a romantic and melancholic gaze of jungle-covered temples and toward the social relations around them (2008:196). In turning to ruins as "epicenters of renewed claims, as history in a spirited voice" Stoler hopes that such examinations might uncover "new possibilities, bids for entitlement, and unexpected political projects" (2008:198). Stoler's framework of "remains" is another way to see the accumulation of the landfill and the people who live in it. Trash accumulates there, but so 
does life. Just as Indonesia and Jakarta have colonial inheritances from Dutch and Japanese imperialism, lives accumulating on the remains at the landfill inherit the precarious value and character of waste, as well as the history of the site. Those lives can also challenge that precarity.

Geographer Tim Edensor (2005) writes about the relationships between social order and the order of material things. He looks at how the meanings and practices around the proper positioning of things in space produce and reproduce dominant cultural values in a constant effort to avoid the sense of disorder that comes with objects out of place. Edensor also looks at the physical ruins of industrial sites, left behind as manufacturing has moved on to new forms or moved elsewhere (Edensor 2005).

Edensor reads the "production of waste and its intensified disposal at both institutional and individual levels" as a "response to a speeded up, capitalist modernity which requires that the material world is more rigorously regulated" (Edensor 2005:313). Under capitalism, to make room for the new, the old must be disposed of (Edensor 2005). In order to maintain order, the old is identified as "irrelevant, dirty and disorderly," and must be disposed of (Edensor 2005:315). This matter out of place, this trash, is removed and order is maintained through "regimes of disposal" (Edensor 2005:315). The trash must not only be identified as such, it must be removed and erased. The regimes of disposal work to move trash away from those whose normative engagements have produced it by deeming it unworthy of being kept. Once erased, order is restored. Waste pickers challenge these regimes of disposal by confronting the trash and asserting its usefulness, and in doing so, they deny the waste as garbage. As a result are perceived by the trash-producers as disordering the world and challenging the power of trashproducers. 


\section{Waste Picker Social Movements: Peasants, Indigeneity and Resource Extraction}

Associação dos Catadores do Aterro Metropolitano de Jardim Gramacho (ACAMJG), the organization of pickers at Jardim Gramacho, Brazil has between 2,500-3,000 members. Tião, leader of the pickers association noted "When we started this association everyone was laughing at us" (Walker, et al. 2010). However, as a result of organizing, they were able to get local municipality to pave the roads and install a sewage system. In Chennai India, the Kodangaiyur dumpyard receives 1,984 tons of garbage daily, supporting 3,000 Waste Pickers. Under pressure from a local resident's association, the Chennai Corporation built a wall around the dump in 2011 to prevent the waste pickers from accessing the garbage (Sawant 2010). In Pune, India, the Alliance of Waste Pickers (AIW) held a rally in 2010 drawing pickers from across the nation in order to protect their livelihood from the threat of access restrictions, energy projects that would burn the garbage for power, and other threats to their livelihood (Hemalatha 2011).

Waste picker advocacy organizations in Asia include the Self Employed Women's Association (SEWA), All India Kabari Mazdoor Mahasangh (AIKMM), Kagad Kach Patra Kashtakari Panchayat (KKPKP) and SWaCH Seva Sahakari Sanstha Maryadit (India's first wholly owned cooperative of self employed waste pickers and other urban poor). Women in Informal Employment Globalizing and Organizing (WEIGO) ${ }^{11}$ provides detailed reporting on organizations of waste pickers across the world but has no data on any extant organization in Indonesia. The Global Alliance of Waste Pickers ${ }^{12}$ reports that in April 2012, waste pickers from Asia, Africa, Latin America and Europe participated in the First Global Strategic Workshop in Pune, India. The workshop was hosted by KKPKP, and SWaCH on behalf of the Global Alliance of Waste Pickers, with support from WIEGO.

11 http://www.facebook.com/wiegoglobal and http://wiego.org

12 http://www.facebook.com/GlobalRec and http://globalrec.org 
The report produced by the "First Global Strategic Workshop of Waste Pickers" is titled "Strategic Waste Management" and includes five references to Indonesia. Three of the references are lists of countries in attendance, and two provide summaries of concerns brought to the meeting by the Indonesian representatives. The first is listed under "threats" faced by waste pickers as "Forced eviction, harassment as criminal by community or police." The second is under a section called "take home knowledge and ideas" and it simply says "how to build relationship with the government in a big city and how to organize." While there were detailed reports on waste picker movement progress in Africa, Serbia, India, Bolivia, Brazil, Argentina, Senegal, Egypt, Mali and Phillippines, there was no further information on waste pickers in Indonesia despite Bantar Gebang being a waste picker community of over 2,000 people located in Southeast Asia's largest metropolitan area.

Suggesting another possible approach to waste picker rights, the editor of Reader's Digest Asia frames the picker community in Indonesia as "farmers" when he writes "The crop is unusual and the farmers unlikely, but for the children of Bantar Gebang, making money from recycling other people's plastic trash is a lifeline for their impoverished families" (Moore \& Demopoulos n.d.). By expanding the waste pickers social movement using this identity as farmers, waste pickers could conceivably join forces with transnational agrarian social movements, such as Vía Campesina whose headquarters are next door in Jakarta. Vía Campesina has campaigned for a UN declaration on the rights of peasants by successfully linking peasants rights to the right to food (Edelman 2011) and malnutrition is serious problem for the waste picker community.

In September 2012, the UN Human Rights Council adopted a resolution (A/HRC/21/L23) on the rights of peasants. The "Report of the HRC Advisory Committee - Final study on the 
advancement of the rights of people working in rural areas" identifies hunger "like poverty," as "still primarily a rural problem." Section II of the resolution identifies "peasant farmers, small landholders, landless workers, fisher-folk" and "hunters and gatherers" as the most discriminated against and vulnerable groups. Although an argument could easily be made that the waste pickers at Bantar Gebang, and elsewhere, are landless people working as "agricultural laborers" (one of the categories identified in the resolution) or "peasant farmers," waste collection is not mentioned anywhere in the resolution. Waste pickers appear to be overlooked in this case not only because their "crop" or "gathering" labor is not viewed as traditional but also because of their location on the urban periphery; they are not seen as fitting in either urban or rural communities. This is in part because of the kampung-like character of the waste picker community which is reflected in their informality, poverty, and maintenance of rural traditions in an urban setting.

Additionally, waste pickers in India and elsewhere in Asia are placed at odds with UN sponsored development plans as they protest UN plans for waste-to-energy incineration plans which threaten to destroy or seize control of their homes, land, and livelihood. Through the Global Methane Initiative (GMI), ${ }^{13}$ TPA Bantar Gebang Landfill (the administrative agency in charge of the site) has begun extracting methane from the landfill. Founded in October 2010 by 38 governments, the European Commission, the Asian Development Bank and the InterAmerican Development Bank the GMI promotes methane extraction as a solution to the threat of global climate change. GMI promotes methane recovery and use from landfill and other sites to prevent methane gas, the second most harmful Greenhouse Gas, from escaping into the atmosphere (GMI Fact Sheet ${ }^{14}$ ). This threat from a resource extraction corporation open new

$13 \mathrm{http}: / /$ www.globalmethane.org

$14 \mathrm{http} / / / \mathrm{www}$. globalmethane.org/documents/gmi_factsheet.pdf

M. Oman-Reagan 16 
opportunities for organization and solidarity as it situates the waste pickers at Bantar Gebang in a position of indigeneity in Indonesia.

Anthropologist Anna Tsing looks at claims about the "indigenous" by activists, community leaders, and public intellectuals to follow the discursive frames constructed by their claims (Tsing 2007). She traces the effect of these frames on the genre conventions which articulate indigenous identity and contribute to the shape of "indigenous voice." Tsing offers a critique of two common research models used in evaluating indigeneity: case studies and generalizations. Case studies, she argues, string together cases with an assumption of commonality, and analysis looks for universal principles without attention to the specific. Both models, Tsing argues, "reduce indigeneity to a singular set of logics and dilemmas." To counter these models, Tsing seeks a historically situated history of the diversity of the indigenous. This framework for considering indigenous voice is well suited to understanding the intersections of the local and global waste picker movements with extant indigenous social justice activism and organizations.

In Indonesia, the phrase used to refer to "indigenous people" is masyarakat adat (customary society). The official motto of Indonesia, Bhinneka Tunggal Ika, usually translated as "unity in diversity" is a reference to the idea of a national identity uniting the Indonesian people despite ethnic, and other, differences. A related concept, Persatuan Indonesia (Unity of Indonesia) serves as the third principle of Pancasila, the philosophical foundation of the Indonesian state laid out in the 1945 constitution. This focus on unity produces opposition to attempts to distinguish populations of indonesians (indigenous, rural, peasant, etc.) from other Indonesians. Historically, this principle of unity was important to Indonesians as a means of fighting the "divide and conquer" methods of imperial and colonial regimes (Tsing 2007). Under 
Dutch colonial rule, adat (custom, customary, traditional ideology) was elevated to the status of law, and used to frame indigenous cultures and their practices as traditional and natural in opposition to Islam, which was positioned as an invading religion and culture (Tsing 2007). The first national meeting of Indonesian Indigenous People was held in 1999, when the Aliansi Masyarakat Adat Nusantara ${ }^{15}$ (AMAN) was formed (Tsing 2007).

Tsing writes about one Indonesian activist who explained that her definition of masyarakat adat (indigenous people of Indonesia) was "rural communities fighting resource corporations" (2007). This definition demonstrates the expanded notion of "indigenous" in use by activists in Indonesia. This same broad meaning could be used to apply indigenous identity to waste pickers in terms of their shared interests and struggles with other marginalized communities. Further, Tsing argues that transnational links between indigenous people build indigenous definitional frames on the basis of transnational concerns (such as environmentalism). In one example from the 1980s, Brazilian indigenous environmentalists translated their campaign to save the Amazonian rainforest to Southeast Asia giving rise to a globalized rainforest campaign which afforded indigenous people around the world an opportunity to take on the role of environmental stewards (Tsing 2007). This globalizing of definitional frames and resulting relationships between indigenous people represents one way online organization can serve the interests of social movements. As Adam Lucas suggests, new media technologies offer solutions to communication between native peoples spread across the vast continents of North America and Australia (1996). He proposes that this kind of communication networking makes it easier for native peoples to "compare and contrast their respective social, cultural and political situations" (Lucas 1996:104).

15 Translation: Alliance of Indigenous Peoples of the Archipelago 


\section{Conclusion:}

My first exposure to waste pickers came from reading Kate Hodal's 2011 article in the Guardian about the community at Bantar Gebang. I began this research project with the desire to learn more about the waste picker community and with the hope that I would find an existing online presence for a waste picker social movement in Indonesia. Despite Indonesia having some of the highest levels of internet penetration in Southeast Asia the waste picker community at Bantar Gebang has not yet taken advantage of or has not yet had the opportunity to access the political potential of online social media. Unlike other social justice movements in Indonesia I have studied (such West Papuan independence, anti-corruption causes and GLBTetc. rights) the waste picker's cause has also not yet been adopted by the Indonesian Occupy Movement.

While there are a few advocacy groups on Facebook, their membership and activity is low. Increased activity on social media sites by waste pickers at Bantar Gebang, especially around the issue of increasing recycling and reducing incineration of waste, would not only benefit their community but contribute to efforts by Jakarta's municipal government to educate metropolitan area residents about recycling and waste sorting practices. Additional research needs to be done, preferably through ethnographic fieldwork on-site, to better understand the desires, needs and hopes of the residents at Bantar Gebang regarding their situation. Assuming the residents are interested in organizing to gain power and more influence on what happens at the landfill, introducing internet access through mobile devices would be a relatively easy and inexpensive way to help this community gain that voice. Internet access from mobile devices would also allow them to join and influence the global waste picker social movement. As a waste picker community on the periphery of Southeast Asia's largest urban area, the voices of the thousands of residents and workers at Bantar Gebang need to be heard. 


\section{References Cited}

Baichwal, Jennifer, dir.

2006 Manufactured Landscapes. Zeitgeist Films.

Bainbridge, Nur

2012 Waste Pickers Have Feelings Too, Jakarta Post, June 7, 2012.

http://www.thejakartaglobe.com/talkback/waste-pickers-have-feelings-too/522891, accessed October 19, 2012.

Boellstorff, Tom, George E. (FRW) Marcus, Bonnie Nardi, Celia Pearce, and T. L. L. Taylor 2005 The Gay Archipelago: Sexuality and Nation in Indonesia. Princeton Univ Pr.

Chaerul, M., M. Tanaka, and A. V. Shekdar

2007 Municipal Solid Waste Management in Indonesia: Status and the Strategic Actions. Journal of the Faculty of Environmental Science and Technology, Okayama University 12(1): 41-49.

Cutler, Kim-Mai

2010 "Indonesia Eclipses the UK as Facebook's Second Largest Market"

http://www.insidefacebook.com/2010/11/02/indonesia-facebook/, accessed October 1, 2012.

Cybriwsky, Roman and Ford, Larry R.

2001 City profile: Jakarta. Cities 18(3): 199-210

Damanhuri, E., and J. Ganesa

2004 Waste Minimization as Solution of Municipal Solid Waste Problem in Indonesia. In The 6th ASIAN Symposium on Academic Activities for Waste Management, PadangIndonesia Pp. 11-13.

Darabi, Leila

2008 First World Congress of Waste Pickers. Everydaytrash.

http://everydaytrash.com/2008/04/22/first-world-congress-of-waste-pickers/, accessed

October 1, 2012.

Davis, Mike

2007 Planet of Slums. Verso.

2006 Planet of Slums. New Perspectives Quarterly 23(2): 6-11.

Edelman, M., and C. James

2011 Peasants' Rights and the UN System: Quixotic Struggle? Or Emancipatory Idea Whose Time Has Come? The Journal of Peasant Studies 38(1): 81-108.

Edensor, Tim

2005 Waste Matter - The Debris of Industrial Ruins and the Disordering of the Material 
World. Journal of Material Culture 10(3): 311-332.

Firman, Tommy

2004 New town development in Jakarta Metropolitan Region: A perspective of spatial segregation. Habitat International 28(3): 349-368.

1998 The restructuring of Jakarta Metropolitan Area: A "global city" in Asia. Cities 15(4): 229-243.

Grazella, Mariel

2012 Billionaires Club Grows Fastest in Indonesia. The Jakarta Post, September 28. http://www.thejakartapost.com/news/2012/09/28/billionaires-club-grows-fastestindonesia.html, accessed October 19, 2012.

Han, Sun Sheng and Basuki, Ann

2001 The spatial pattern of land values in Jakarta. Urban Studies 38(10): 1841-1857

Hemalatha, Karthikeyan

2011 Wall Around Dumpyard to Steal Livelihood of 3000 Waste-pickers. The Times Of India, April 21. http://articles.timesofindia.indiatimes.com/2011-0421/chennai/29458498_1_rag-pickers-dumpyard-recycling, accessed October 2, 2012.

Hodal, Kate

2011 Living Off the Landfill: Indonesia's Resident Scavengers. The Guardian, September 27. http://www.guardian.co.uk/world/2011/sep/27/indonesia-waste-tip-scavengers, accessed October 1, 2012.

Leaf, Michael

1994 The suburbanization of Jakarta: A concurrence of economics and ideology. Third World Planning Review 16(4): 341-356.

Lucas, Adam

1996 “Indigenous People in Cyberspace.” Leonardo 29 (2): 101-108.

Moore, Thomas, and Katherine Demopoulos

N.d. The Kids of Bantar Gebang. Reader's Digest Asia.

http://www.rdasia.com/the_kids_of_bantar_gebang, accessed October 23, 2012.

Obama, Barack

2010 Remarks by the President at the University of Indonesia in Jakarta, Indonesia. The White House. (http://www.whitehouse.gov/the-press-office/2010/11/10/remarkspresident-university-indonesia-jakarta-indonesia)

Pasang, Haskarlianus, Graham A. Moore, and Guntur Sitorus 2007 Neighbourhood-based Waste Management: A Solution for Solid Waste Problems in Jakarta, Indonesia. Waste Management 27(12): 1924-1938. 
Sawant, Snehal Sonawane

2010 Nation-wide Rally to Demand Rights of Waste Collectors. The Times Of India, March 9. http://articles.timesofindia.indiatimes.com/2010-03-09/pune/28141516_1_solid-wasteinformal-collectors-livelihood, accessed October 2, 2012.

Simanjuntak, Lydia Rosintan

2002 Tinjauan Tentang Fenomena Pemulung Dan Penanganan Sampah Di Wilayah DKI Jakarta Dan Bailtar Gebang Bekasi. IPB (Bogor Agricultural University). http://repository.ipb.ac.id/handle/123456789/20001?show=full, accessed October 1, 2012.

Stoler, Ann L.

2008 Imperial Debris: Reflections on Ruins and Ruination. Cultural Anthropology 23(2): 191-219.

Tipple, Mark

2009 Collecting to Survive at Bantar Gebang Waste Landfill. Demotix. http://www.demotix.com/news/267000/collecting-survive-bantar-gebang-waste-landfill, accessed October 1, 2012.

Tsing, A.

2007 “Indigenous Voice.” Indigenous Experience Today: 35-68.

Walker, Lucy, João Jardim, and Karen Harley, dir.

2010 Waste Land. Arthouse Films. 